\title{
„Kochają tylko psy". Psia buda i ludzkie szczenię (w Psich latach Günthera Grassa i Nakarmić kamień Bronki Nowickiej)
}

\section{"Only dogs love". The kennel and human puppy (in Günther Grass' Dog Years and Bronka Nowicka's To Feed the Stone)}

\author{
|Katarzyna Kuczyńska-Koschany
Uniwersytet im. Adama Mickiewicza w Poznaniu
}

\begin{abstract}
The article is an attempt to show the relationship between the dog and the man in chosen literary examples. Among them there are dogs enslaved by a man, i.e. Adolf Hitler's dogs, the dog in the poem Monologue of a Dog Ensnared in History written by Wisława Szymborska and the dog in the novel by Günter Grass Dog Yeas (Hundejahre, 1963). There are also dogs enabling human to live, dogs, who teach man intimacy, freedom and friendship, loving dogs. The most important example here is above all the book of prose written by Bronka Nowicka, entitled To Feed the Stone (2015) and the poem Grandma and Poodle by Danuta Wawiłow.

The author of the essay comes to a conclusion that kennel, dog's fur and dog's presence are in many different ways essential for man not to get lost in the world.

Key words: dog, man, kennel, Günther Grass, Wisława Szymborska, Adolf Hitler, Bronka Nowicka, Danuta Wawiłow

Streszczenie: Tekst jest próbą na temat relacji psa i człowieka w literaturze na wybranych przykładach. To psy zniewolone przez człowieka, czyli psy Adolfa Hitlera, w wierszu Wisławy Szymborskiej pt. Monolog psa zaplatanego w dzieje (2004) i w powieści Güntera Grassa Psie lata (Hundejahre, 1963). To także psy pozwalające człowiekowi żyć, uczące człowieka podmiotowej cielesności, wolności i przyjaźni, partnerskie, kochające. Tu przede wszystkim ważny jest przykład prozy Bronki Nowickiej z tomu Nakarmić kamień (2015) oraz wiersza dziecięcego Danuty Wawiłow pt. Babcia i pudel.

Autorka tekstu konkluduje, że psia buda, psia sierść i psia obecność są wielokrotnie niezbędne, by człowiek nie zagubił się w świecie.

Słowa kluczowe: pies, psia buda, człowiek, Günther Grass, Wisława Szymborska, Adolf Hitler, Bronka Nowicka, Danuta Wawiłow
\end{abstract}

Chcesz-li opisać morderstwo? Pokaż mi psa na podwórzu:

I pokaż mi jednocześnie w oku psa cień tego czynu.

(Hofmannsthal 1984) 


\section{Pies, język(i)}

Psia mać. Psu na budę. Zejść na psy. Skundlić się. Zimno jak w psiarni. Pogoda pod psem. Suka twoja mać. Parszywa sobaka. I tajemnicza wyliczanka szkolna, przytoczona przez Witolda Gombrowicza w Pamiętniku Stefana Czarnieckiego: „Raz, dwa, trzy, wszystkie Żydy psy, a Polacy złote ptacy, a wychodzisz ty" (Gombrowicz 2007, 21) ${ }^{1}$.

Ale przecież to psy liżą rany Łazarza.

Ale przecież bez psa nie byłoby Księgi Tobiasza (dopiero anioł, człowiek i pies czynią całość świata).

\section{Inni}

W najsłynniejszym dziele Franza Kafki ${ }^{2}$ nadgorliwy w sprawie własnego procesu kupiec Blockbaum wchodzi pod łóżko i udaje psa, żeby przypodobać się adwokatowi. Gdy ginie w kamieniołomach Józef K., sam o sobie mówi „jak pies” (Kafka 2016, 197), (w oryginale: „wie ein Hund”3) - wstyd, który ma go przeżyć, jest gorszy niż sama śmierć. Jeden i drugi giną. Kupiec - bo wyzbywa się wszelkiej godności, by ocalić życie; prokurent - zabity pokątnie, przez niewiadomego pochodzenia sąd (nie przez „zwykły sąd”). Wydaje się, że w kulturze europejskiej nic gorszego niż psia dola, owo „jak pies”, nie może się zdarzyć.

Kiedy romskie dziecko umyka przed wyrokiem śmierci nazistów, mamy jednak rewers takiego przekonania (nazwijmy ów rewers empatią):

Na drogach było gęsto od uchodźców, kobiet z dziećmi, kacetników, młodych chłopców i obcych żołnierzy. Wszędzie przy drogach leżały zniszczone pojazdy, ogromne góry żelastwa. I martwi ludzie. Także konie, niektóre całkiem odarte z mięsa i zastrzelone psy z rozprutymi brzuchami. Mano płakał na widok tych psów, a człowiek, który podarł zdjęcie, nieprzyjemnym tonem zapytał, dlaczego płacze.

-Tak mi szkoda tych psów.

-Nad nimi nie musisz płakać - mężczyzna machnął ręką, jakby chciał powiedzieć: co znaczą zabite psy wobec tych wszystkich zabitych ludzi, których widzieli.

Ale Mano i tak płakał nad zwierzętami, nie nad ludźmi. Psy nie mogły się bronić (Tuckermann 2014, 17-18).

Relacja dziecka i zwierzęcia ${ }^{4}$ (zwłaszcza tego zwierzęcia/dziecka, które dało się "oswoić”, które znalazło się zbyt blisko człowieka dorosłego) jest w kulturze miejscem wykluczenia ex definitione. Psy nie mogą się bronić (zwłaszcza „bezpańskie”). Dzieci nie mogą się bronić (zwłaszcza osierocone). Mano płacze nad kimś (podmiotowo) być może jeszcze słabszym niż

\footnotetext{
${ }^{1}$ Por. słynną frazę Maryny Cwietajewej „bce поэты жиды“ z jej Poematu kresu (1924) jako pewnego rodzaju definicję nie normatywności (nienormatywne/i w kulturze europejskiej są: dzieci, zwierzęta, poeci, Żydzi); Barańczak 1995, 152; por. Kuczyńska-Koschany 2013.

2 Który jest także autorem autobiograficznych Dociekań psa (Forschungen eines Hundes, 1922), inspirowanych najprawdopodobniej dialogiem filozoficznym E.T.A. Hoffmana (Nachricht von den neuesten Schicksalen des Hundes Berganza, 1814).

${ }^{3}$ Być może ma to przekonanie swe korzenie w żydowskiej tradycji, traktującej pieskie życie jako życie nędzne. Podobnie jest $w$ islamie.

${ }^{4}$ Pisze o tym w niniejszym zeszycie - obszerniej i mądrzej - Joanna Żygowska. 
on sam, jeszcze bardziej bezradnym, ale przecież przede wszystkim - nad kimś, z kim odnajduje wspólnotę losu. Nad kimś, nie nad czymś. Nie waży śmierci psa jako lżejszej niż ludzka.

\section{Grass (z Szymborską w tle)}

Dwoje noblistów zajęło się psami Hitlera. Zrobili to jednak inaczej. W Psich latach (Hundejahre. Roman, 1963) Güntera Grassa pies Prinz jest szczególnym bohaterem jednego z tomów tzw. trylogii gdańskiej. W wierszu Wisławy Szymborskiej z 2004 roku $^{5}$ pt. Monolog psa zaplątanego $w$ dzieje mówi sam pies:

Są psy i psy. Ja byłem psem wybranym.

Miałem dobre papiery i w żyłach krew wilczą.

Mieszkałem na wyżynie, wdychając wonie widoków

na łąki w słońcu, na świerki w deszczu

i grudy ziemi spod śniegu.

Miałem porządny dom i ludzi na usługi.

Byłem żywiony, myty, szczotkowany,

wyprowadzany na piękne spacery.

Jednak z szacunkiem, bez poufałości.

Każdy dobrze pamiętał, czyim jestem psem.

Byle parszywy kundel potrafi mieć pana

Ale uwaga - wara od porównań.

Mój pan był panem jedynym w swoim rodzaju.

Miał okazałe stado chodzące za nim krok w krok

i zapatrzone $w$ niego z lękliwym podziwem.

Dla mnie były uśmieszki

z kiepsko skrywaną zazdrością.

Bo tylko ja miałem prawo

witać go w lotnych podskokach,

tylko ja - żegnać zębami ciągnąc za spodnie.

Tylko mnie wolno było

z głową na jego kolanach

dostępować głaskania i tarmoszenia za uszy.

Tylko ja mogłem udawać przy nim, że śpię,

a wtedy on się schylał i szeptał coś do mnie.

Na innych gniewał się często i głośno.

Warczał na nich, ujadał

biegał od ściany do ściany.

Myślę, że lubił tylko mnie

i więcej nigdy, nikogo.

Miałem też obowiązki: czekanie, ufanie.

Bo zjawiał się na krótko i na długo znikał.

Co go zatrzymywało tam, w dolinach, nie wiem.

Odgadywałem jednak, że to pilne sprawy,

co najmniej takie pilne

\footnotetext{
${ }^{5}$ Pierwodruk: „Twórczość” 2004, nr 5.
} 
jak dla mnie walka z kotami

i wszystkim, co się niepotrzebnie rusza.

Jest los i los. Mój raptem się odmienił.

Nastała któraś wiosna,

a jego przy mnie nie było.

Rozpętała się w domu dziwna bieganina.

Skrzynie, walizki, kufry wpychano na samochody.

Koła z piskiem zjeżdżały w dół

i milkły za zakrętem.

Na tarasie płonęły jakieś graty, szmaty,

żółte bluzy, opaski z czarnymi znakami

i dużo, bardzo dużo przedartych kartonów,

z których powypadały chorągiewki.

Snułem się w tym zamęcie

bardziej zdumiony niż zły.

Czułem na sierści niemiłe spojrzenia.

\section{Jakbym był psem bezpańskim,}

\section{natrętnym przybłędą,}

którego już od schodów przepędza się miotłą.

Ktoś zerwał mi obrożę nabijaną srebrem.

Ktoś kopnął moją miskę od kilku dni pustą.

A potem ktoś ostatni, zanim ruszył w drogę,

wychylił się z szoferki

i strzelił do mnie dwa razy.

Nawet nie umiał trafić, gdzie należy,

bo umierałem jeszcze długo i boleśnie

w brzęku rozzuchwalonych much.

\section{Ja, pies mojego pana.}

(Szymborska 2016, 411-414, podkreśl. KKK)

Ostatni wers jest niejako konkluzją autoidentyfikacyjną. Mówiącego psa (nadpsa? ${ }^{6}$ ) - zaplątanego przez człowieka (nadczłowieka?) w dzieje - ogranicza punkt widzenia tego, kto go oswoił, hołubił, kształtował. Oczywiście, my wiemy, że to Hitler ${ }^{7}$. Pies jest rasistą. Sam uważa się za rasowego, inne psy to kundle, przybłędy. Potem - nagle - i właściwie bez winy wyróżnionego los się odmienia. Pies pana, wodza, staje się psem bezpańskim, niewodzowskim, ale nie przestaje postrzegać świata w kategoriach własnej wyższości (owego ekskluzywizmu: „tylko ja”, „tylko mnie”).

Najciekawsza w tym wierszu jest interferencja zwierzęco-ludzka. Przenikanie rasizmu w jedną stronę, a warczenia, ujadania - w drugą; podobne z podobnym spotyka się tu i uzupełnia. Los psa Hitlera powtarza

${ }^{6}$ Podobne mówiące psy pojawiają się w powieści Ryszarda Marka Grońskiego Szlemiel, jej narrator - buldog francuski, członek rodziny zasymilowanych polskich Żydów, już w przededniu wybuchu II wojny światowej podczas spacerów spotyka wrogo nastawionego, przejawiającego rasistowskie uprzedzenia, foksteriera, należącego do sekretarza niemieckiej ambasady.

7 Pisze o tym Wojciech Ligęza we wstępie do wyboru wierszy Szymborskiej: „Wiersz nawiązuje do fragmentu biografii Adolfa Hitlera (...). Ukochanym psem dyktatora, często występującym na fotografiach, był owczarek alzacki Blondi"(Szymborska 2016, 411).

\section{Polonistyka. Innowacje}


los wodza Trzeciej Rzeszy, jego całkowitą klęskę. A jednocześnie można to przecież czytać inaczej: jako ofiarę ${ }^{8}$ czy też istotę zinstrumentalizowaną przez złego człowieka.

U Grassa inaczej, bo pies Prinz odzyskuje wolność, ucieka w ostatniej właściwie chwili. Sam tytuł książki konotuje „złe lata”, „trudne lata”, ale jest też psią sagą $\mathrm{z}$ wielokrotnie powtarzanym rodowodem, jakby celowo przedrzeźniającym rodowody aryjskie i ideologię Lebensbornu. Apokryf psio-hitlerowski pojawia się przy słowach: „Była sobie kiedyś dziewczynka, która nazywała się Tulla i miała czyste, dziecięce czoło. Ale nic nie jest czyste” (Grass 2007, 361), a kończy na akapicie: „Był sobie kiedyś pies, który opuścił swego pana i przebył długą drogę" (Grass 2007, 432). Zajmuje zatem 70 stron w książce, która liczy ich ponad 700, „dziesiątkuje” ją w szczególny sposób. I konsekwentnie stylizuje na ciemną baśń, jak ze zbioru braci Grimm, wskazując - być może pośrednio - na źródła nazistowskiej wyobraźni.

Losy Tulli Pokriefke, konduktorki tramwajowej, dziewczyny, która wie, że kości, zwożone na stos w Gdańsku Wrzeszczu, są ludzkie (prosto ze Stutthofu), dziewczyny w tajemniczy sposób brzemiennej, która poroni w drugim miesiącu ciąży, splatają się z losami psa Hitlera. Przyjaciel Tulli, Harry Liebenau (i emocjonalny ojciec jej dziecka), opowiada rodzicom:

Był sobie kiedyś pies,

który nazywał się Perkun. Ten pies spłodził sukę Sentę. A Senta urodziła Harrasa. A Harras spłodził Prinza. I wiecie, gdzie właśnie zobaczyłem naszego Prinza? Na kronice tygodniowej. W kwaterze głównej. Między führerem a Rudlem. Na dworze, bardzo wyraźnie. Mógłby to być również nasz Harras (Grass 2007, 382-383).

Rodowód psa jest przedstawiony w powieści Grassa bardzo dokładnie:

Był sobie kiedyś pies,

który nazywał się Perkun i należał do litewskiego młynarczyka, co to znalazł pracę u ujścia Wisły. Perkun przeżył młynarczyka i spłodził Sentę. Suka Senta, która należała do młynarza z Mikoszewa, urodziła Harrasa. Ten reproduktor, który należał do stolarza z Gdańska-Wrzeszcza, pokrył sukę Teklę, będącą własnością niejakiego pana Leeba, zmarłego na początku czterdziestego drugiego, wkrótce po suce Tekli. Natomiast pies Prinz, spłodzony przez owczarka Harrasa i urodzony przez sukę Teklę, przeszedł do historii: został podarowany na urodziny führerowi i kanclerzowi i jako jego ulubiony pies trafił do kroniki tygodniowej.

Kiedy chowano hodowcę psów Leeba, stolarz poszedł na pogrzeb hodowcy. Kiedy umarł Perkun, w księdze hodowlanej zapisano normalną psią chorobę. Sentę, ponieważ wpadła w histerię i narobiła szkód, trzeba było zastrzelić. Suka Tekla zgodnie z zapisem w księdze hodowlanej zdechła na uwiąd starczy. Natomiast Harrasa, który spłodził Prinza, ulubionego psa führera, otruto z powodów

\footnotetext{
${ }^{8}$ Ta egzekucja zwierzęcia może kojarzyć się z losem psa, któremu wspomnienie poświęciła Hélène Cixous (Stigmata or Job, the Dog), francuska filozofka opowiada, jak należący do jej rodziny Fips stał się ofiarą wojny francusko-algierskiej. Co ciekawe, podobną równie dramatyczną historię przytacza Olga Tokarczuk (2012, 59-60), w 1946 roku w wyniku repatriacji rodzina jej ojca zmuszona została do porzucenia psa, którego nie pozwolono im zabrać do pociągu; por. Barcz 2016, 113-116; 261.
} 
politycznych zatrutym mięsem i pogrzebano na psim cmentarzu. Została po nim psia buda (Grass 2007, 393).

Psia buda staje się osobną bohaterką opowieści snutej przez Grassa. Kiedy Harry, syn stolarza Liebanaua, zgłosił się jako ochotnik do marynarki wojennej 20 kwietnia 1944 roku, ten porąbał psią budę otrutego Harrasa, „bez słowa, samotnie”, „w drobny mak” (Grass 2007, 396):

Ponieważ dwudziestego kwietnia obchodzono wszak pięćdziesiąte piąte urodziny tego samego führera i kanclerza, któremu dziesięć lat temu ofiarowano w prezencie młodego owczarka Prinza z rodu Harrasa, wszyscy w oknach czynszowej kamienicy i przy strugnicach stolarni pojęli, że porąbane zostało coś więcej niż spróchniałe drewno i podziurawiona smołowana papa (Grass 2007, 396).

(To także czas nieudanego zamachu na Hitlera: pies i jego pan cudem ocaleli, zamachowca zaś powieszono).

Podczas kolejnych, jak się potem okazało - ostatnich - urodzin Hitlera, pięćdziesiątych szóstych, obchodzonych w berlińskim bunkrze, Prinz gdzieś znika. Ucieka od swego pana. „Bo nie było stałego psiego tutaj psiego tam psiego teraz. (...) Bo żadnej swobody. Bo wciąż na terenie zastrzeżonym" (Grass 2007, 428). Ucieczkę Prinza z „zaduchu bunkra” Grass opisuje brawurowo, piękne jest zwłaszcza i symbolicznie znaczące jej zakończenie:

Był sobie pies,

który opuścił swego pana i przebył długą drogę. Tylko króliki marszczą nos; lecz nikt, kto umie czytać, niech nie sądzi, że pies nie dotarł.

Ósmego maja tysiąc dziewięćset czterdziestego piątego roku, o czwartej czterdzieści pięć rano, przepłynął Łabę powyżej Magdeburga prawie niezauważony i na zachodnim brzegu rzeki zaczął szukać sobie nowego pana (Grass 2007, 432, podkreśl. KKK).

\section{Debiutantka, przemoc, psy}

Bronka Nowicka debiutuje po czterdziestym roku życia - przedtem jest już scenarzystką, reżyserką, absolwentką łódzkiej Filmówki i krakowskiej ASP. Debiutancki tom o doświadczaniu przemocy i jej przepracowaniu (czy może raczej: prze-pisaniu) pt. Nakarmić kamień od razu uhonorowano nagrodą Nike.

Rozpoczyna się ta potworna opowieść, dedykowana Niemożliwemu, od smutku („Smutek mnie uczy, że służę do życia” (Nowicka 2015, 7)), który mówi do pierwszoosobowej bohaterki o jej własnej daremności: „W zasadzie jesteś sobie potrzebna prawie do niczego" (Nowicka 2015, 7).

Relacja dziewczynki i suki, dziewczynki niekochanej i poddawanej przemocy, samotnej jako dziecko i podczas dorastania, ta relacja jest - i tak to trzeba nazwać bez przesady, bez obawy, że słowo zbyt duże - ocalająca:

Dziecko chce mieszkać w suczym brzuchu. Rodzić się w nocy, być lizane z krwi, rano wracać: czołgać się do domu przez tunel w psie. 
W kieszeni ma chleb ze smalcem, stoi przy drucianej siatce i czeka. Kiedy stoi się dostatecznie długo, zwierzę przychodzi. Tylko po chleb, bo nie chce, żeby człowiek, nawet mały, wprowadzał mu się do środka.

- Będę w tobie grzeczna.

Suka chce jeść, ale nie jest do wynajęcia. Łyka chleb i toczy się w dół ulicy, stara i wytarta na bokach. Przez kolejne dni wraca i patrzy na kieszeń, z której w obie strony wyrasta dziecko.

- Zdejmę buty, nie pobrudzę cię.

Suka odchodzi, gdy zliże okruchy z chodnika.

Po kilku tygodniach palec przerzucony przez metalowe oko na drugą stronę siatki drapie psi łeb tak długo, aż opuszka pokrywa się czarną mąką. Suka zamyka oczy, może nawet śpi oparta o płot. Wtedy dziecko myśli, jak układa się w brzuchu wyściełanym sierścią. Jak brzuch zabiera je, gdzie nigdy nie było.

Kiedy kończy się lato, suka przestaje przychodzić. Dziecko wytrzepuje kieszeń z okruchów. Od psich myśli ma zaropiałe oczy i wydrapane na czerwono placki.

- Nie podchodźcie do niej - mówią. - Śmierdzi budą (Siatka, Nowicka 2015, 22, podkreśl. KKK).

Dziewczynka szanuje sukę. Traktuje ją jak starszą, mądrzejszą. A przecież jednocześnie - delikatnie oswaja. Odnajdują w sobie nawzajem czułość, ciepło ciała, oczywistość pieszczoty (brzuch suki zabiera dziecko, „gdzie nigdy nie było" - daje dziewczynce to, czego nigdy nie doświadczyła, gdyż dorośli wokół niej są zatrzaśnięci w swych rolach na zawsze, oschli, nieprzytulalni ${ }^{9}$ ). Dziewczynka i suka obdarzają się somatycznym zaufaniem, wielką wyobraźnią zwierzęco-ludzkiego sojuszu, przyjaźni, bliskości.

Także ojciec dziewczynki, postać winna braku miłości, zła i kradzieży (kradł, fotografując: „Ojciec jest winien pejzażom setki chmur i domów, kilku psom budy, a ludziom - tym jeszcze żywym i już umarłym - twarze", Nowicka 2015, 39), braku komunikacji i rozpadu więzi, staje się (trochę) inną istotą dzięki zwierzętom (to on, już „przemieniony”, wypowiada słowa tytułowe mojego tekstu):

Pewnego dnia ojciec założył prawdziwą skórę uszytą na miarę.

Była mniej różowa, ale grubsza od poprzedniej. Sprawił też sobie żółte zęby i pięty. Siadał na ziemi i mówił. Najpierw tylko przy zwierzętach. Początkowo były to małe zwierzęta, takie jak pająki czy ćmy. Po jakimś czasie nie wstydził się przemawiać przy ptakach i kundlach. Później przy dzieciach. Potem ojciec mówił do siebie przy wszystkich. Stawał przed lustrem i patrzył w nie, jakby było oknem. Nikt nie wie, co tam widział, ale chciał konsultować się w tej sprawie z Bogiem.

Puka w stół.

- Kto tam? - pytał.

- Pan Bóg - odpowiadał, jakby samo słowo mogło sprowadzić Boga do kuchni.

Próbował też do niego dzwonić. Bóg nie odbierał.

Ojciec powiedział mi:

- Kiedy byłem chłopcem, widziałem szatana. Ma czarny kapelusz.

Powiedział jeszcze:

- Kochają tylko psy.

${ }^{9}$ Neologizm domowy mojej córki, Lenki. 
To wszystko, co powiedział mi ojciec. Resztę rzeczy zostawił dla siebie (Skóra, Nowicka 2015, 52, podkreśl. KKK).

Twierdzenie, że „kochają tylko psy” i ta gradacja: coś ważnego robimy najpierw tylko przy zwierzętach (małych, potem coraz większych) potem przy dzieciach i dopiero potem przy wszystkich, to dwie prawdy o niesamodzielności człowieka, który nie potrafi się wykluć, wylizać, wygrzebać (bo umarło w nim zwierzę) i który ufa eleganckiemu kusicielowi w czarnym kapeluszu.

Najpiękniejsza może, a na pewno najbardziej poruszająca, widmowa i poważna, opowieść o solidarności i przyjaźni człowieka z psem pojawia się w Latawcach, których prawdziwość - nawet jeśli niemimetyczna - jest zawarowana jako wiarygodne świadectwo dziecka (takiego Andersenowskiego, które zawsze mówi najtrudniejszą prawdę):

Ten człowiek i pies mieli pergaminowe skóry oraz połapane sznurkiem kości, puste w środku i dziurawe, bo gdy mocniej zawiało, obaj popiskiwali jak flety.

Kiedy szli, nie robili już nic innego. Jeśli człowiek chciał coś powiedzieć psu, przystawał. Pies robił to samo, chcąc popatrzeć na człowieka. Łączenie czynności w pary było zadaniem ponad ich siły. Tylko czasami człowiek mlaskał, gdy szedł. Widocznie język był sekundnikiem jego wewnętrznego zegara, ciągle dającego się nakręcać.

Pies miał nad człowiekiem przewagę, która polegała na dwóch nogach więcej, dlatego wyprzedziwszy go o krok, zatrzymywał się i czekał, żeby się zrównali. To trwało.

- Może wie, jak go wołam, może słyszał? - pytał nieraz człowiek przechodnia i pokazywał psa, bo zdarzało się człowiekowi zapomnieć jego imienia, tak jak psu zdarzało się zapomnieć drogi do domu. - Zawsze tu chodzimy - zataczał koło bambusowym palcem, bo nie był pewien, czy na tyle drzew mówi się tartak, park czy las. Ostatecznie nie miało to większego znaczenia, podobnie jak imię - czyjeś, a nawet własne.

Przyszedł czas, gdy człowiek i pies zrobili się tak przezroczyści, że można było oglądać przez nich zakrzywiony świat, jak przez szklanki.

Przyszedł też silniejszy wiatr, więc chodzili jeszcze bliżej siebie dla pewności, że jeśli ich porwie, polecą razem.

Podniosło ich do góry, a oni wciąż przebierali nogami, chociaż już nie musieli. Po jakimś czasie wyglądali jak latawce, jeszcze później jak dwie kropki, które mogą być równie dobrze ptakami, co złudzeniem.

Dziecko widziało, chociaż nikt mu nie wierzy (Latawce, Nowicka 2015, 38, podkreśl. KKK).

Są zwierciadłem tego świata, są synonimem prawdziwej bliskości. Jeśli dotyka ich przemiana, to tylko wspólnie. W antropologii mówi się, że nie ma więzi silniejszej niż ta między matką a dzieckiem (zwłaszcza między matką a córką); w nowej refleksji zwierzęco-ludzkiej nie ma więzi silniejszej niż ta między ssakiem a ssakiem (zwłaszcza między człowiekiem a psem) ${ }^{10}$.

${ }^{10}$ Albo kotem, oczywiście; por. Swan Madeline, 2015, Historia kotów, Wojtyna M., Aleksandrowicz-Wojtyna M. (przeł.), Kraków. 


\section{Domknięcie: babcia, pudel, emancypacja}

Na koniec bardzo poważny żart Danuty Wawiłow, jej wiersz zatytułowany Babcia i pudel. Najczęściej czyta się go jako przykład anarchicznego humoru, beztroskiego nonsensu z dobrą pointą. Otóż postawiłabym śmiałą hipotezę, że pudel wyzwala babcię, uczy ją asertywności, czyli umiejętności niezgody na jakiś stan. Babcia buntuje się wobec beztroski psa, używa jego mowy (warczy) i jego broni (gryzie w ucho). Twórcze wejście w rolę zwierzęcia przywraca harmonię domową, co ciekawe, wzbogacając ją o wymiar anarchiczny, zabawowy, swobodny. Razem - stara kobieta i zwierzę - są już potem tylko i aż wolni:

Była sobie babcia, miała serce złote, miała także pudla, wielkiego niecnotę.

Poszła do ogródka narwać trochę marchwi, wraca i co widzi? Pudel leży martwy!

Poszła do grabarza, smutna i spłakana, wraca i co widzi? Pies biega po ścianach!

Poszła więc do kuchni postawić makaron, wraca i co widzi? Pies pali cygaro!

Poszła po szydełko, by mu zrobić sweter, wraca i co widzi? Pies czyta gazetę! Babcia na ten widok zawarczała głucho, skoczyła na pudla, ugryzła go w ucho.

Odtąd pudel z babcią żyją w wielkiej zgodzie, fikają koziołki, bawiąc się w ogrodzie. (Wawiłow 1993, 39)

\section{Bibliografia:}

Baratay Éric, 2014, Zwierzęcy punkt widzenia. Inna wersja historia,

Tarasewicz P. (przeł.), Gdańsk.

Barcz Anna, 2016, Realizm ekologiczny. Od ekokrytyki do zookrytyki, Katowice. 
Gombrowicz Witold, 2007, Pamiętnik Stefana Czarnieckiego, w: Bakakaj i inne opowiadania, Kraków.

Grass Günter, 2007, Psie lata, Błaut S. (przeł.), Warszawa.

Groński Ryszard Marek, 2010, Szlemiel, Warszawa.

Hofmannsthal Hugo von, 1984, Liryka. Wiersze i dramaty, Lewin L. (wybrał i przeł.), Warszawa.

Kafka Franz, 2016, Proces, Ekier J. (przeł.), Ekier J., Musiał Ł. posłowia, wyd. II, przejrzane, Łódź.

Krupiński Piotr, 2016, „Dlaczego gęsi krzyczały?”. Zwierzęta i Zagłada $w$ literaturze polskiej XX i XXI wieku, Warszawa.

Kuczyńska-Koschany Katarzyna, 2013, „Bсе поэты жиды“. Antytotalitarne gesty poetyckie i kreacyjne wobec Zagłady oraz innych doświadczeń granicznych, Poznań.

Nowicka Bronka, 2015, Nakarmić kamień, Wrocław.

Swan Madeline, 2015, Historia kotów, Wojtyna M., Aleksandrowicz-Wojtyna M. (przeł.), Kraków.

Szymborska Wisława, 2016, Monolog psa zaplątanego w dzieje, w: Wybór poezji, Ligęza W. (wstęp i oprac.), Wrocław.

Tokarczuk Olga, 2012, Moment niedźwiedzia, Warszawa.

Tuckermann Anja, 2014, Mano. Chłopiec, który nie wiedział, gdzie jest, Bratkowska K., Ciurapińska K. (przeł.), Warszawa.

Wawiłow Danuta, 1993, Babcia i pudel, w: Wierszykarnia, Borowski T. (il.), Warszawa.

\section{O Autorce:}

Katarzyna Kuczyńska-Koschany - prof. w Instytucie Filologii Polskiej UAM, polonistka, komparatystka, eseistka, prozaik. Autorka książek: Rilke poetów polskich (2004; wydanie II - 2017), Rycerz i Śmierć. O „Elegiach duinejskich" Rainera Marii Rilkego (2010; wyd. II, e-book, 2015), Interlinie w ciemności. Jednak interpretacja (2012), „Все поэты жиды“. Antytotalitarne gesty poetyckie i kreacyjne wobec Zagłady oraz innych doświadczeń granicznych (2013), tomu prozy Zielony promień (2006), współautorka podręcznika dla maturzystów Staropolskie korzenie współczesności (2004). Należy do Rad Naukowych „Miasteczka Poznań” oraz „Narracji o Zagładzie”. Członkini: Zespołu Badań nad Literaturą Zagłady IBL PAN, Komitetu Nauk o Literaturze PAN, Otwartej Rzeczpospolitej, komisji ds. przeciwdziałania dyskryminacji przy Rektorze UAM. Opiekunka Koła Naukowego Miłośników Kultury i Literatury Żydowskiej „Dabru met” (UAM). Obecnie kieruje Pracownią Badań nad Tradycją Europejską IFP UAM. 